\title{
APPLICATION OF REMOTE SENSING INDICES IN DETERMINING THE INTERRELATION BETWEEN CONDITION OF TREE STANDS AND MYRMECOFAUNA IN FORESTS OF WIGRY NATIONAL PARK
}

\author{
Michą T. Chiliński, Katarzyna Czajkowska, Lech Krzysztofiak, Pawee J. Mazurkiewicz
}

\begin{abstract}
M.T. Chiliński, Laboratory of Image-based Information, Faculty of Biology, University of Warsaw, Miecznikowa 1, 02-096 Warsaw, Poland, e-mail: mich@igf.fuw.edu.pl

K. Czajkowska, Laboratory of Ethology, Nencki Institute of Experimental Biology PAS, Pasteura 3, 02-093 Warsaw, Poland, e-mail: kaczajkowska@gmail.com

L. Krzysztofiak, Wigry National Park, Krzywe 82, 16-402 Suwałki, Poland, e-mail: krzysztofiak.lech@gmail.com

P.J. Mazurkiewicz, Laboratory of Ethology, Nencki Institute of Experimental Biology PAS, Pasteura 3, 02-093 Warsaw, Poland, e-mail: pawel.j.mazurkiewicz@gmail.com

Department of Animal Physiology, Faculty of Biology, University of Warsaw, Miecznikowa 1, $02-096$ Warsaw, Poland,

College of Inter-Faculty Individual Studies in Mathematics and Natural Sciences, University of Warsaw, Żwirki i Wigury 93, 02-089 Warsaw, Poland
\end{abstract}

(Received: September 28, 2018. Accepted: October 26, 2018)

\begin{abstract}
AвSTRAct. Presented work is aimed at investigating potential correlations between remote sensing vegetation indices and local ant populations. Research was conducted in summer of 2017 in Wigry National Park in two types of forest habitats: coniferous (Serratulo-Pinetum) and deciduous (Tilio-Carpinetum). NDVI and MCARI2 vegetation indices were measured with the use of a drone and yielded comparable correlations with ant-related quantities. We determined that the presence of ants from Formica group is positively correlated with vegetation indices, while the correlation between Myrmica and Lasius ants and vegetation indices is more complex.
\end{abstract}

KEY WORDS: red wood ants, myrmecofauna, forest ecosystems, vegetation indices, remote sensing, RPAS, drone, NDVI

\section{INTRODUCTION}

The great impact of ants (Hymenoptera, Formicidae) on environment is a well-known phenomenon. The presence of ants is recorded in almost all inland environments, in many of which ants are crucial species in economic context (e.g. in HölLDObler \& WiLsoN 2009). Ants are abundant in number and they forage on a wide range of food types, therefore positively influencing the "sanitary state" of forests. Basing on this fact, two red wood ant species (Formica polycte$n a$ and Formica rufa) were given protection by law in Poland (CZeCHOwsKi et al. 2012). The immediate impact of red wood ants on the condition of tree stands is a subject to broad discussion and the results of research on this topic are still inconclusive (ADLUNG 1966, OHASHi et al. 2007, Frouz \& JiLKova 2008, FARJi-Brener \& WerenkraUt 2017).

Remote sensing techniques have recently become widely used for assessment of ecosystems state (usually considered as condition/richness of vegetation) by means of various spectral indices (Prentice et al. 1992, GAmon et al. 1995, Asner 1998, ZhANG et al. 2003). Estimations are based on changes of absorption (on different wavelengths) of light by plant organs. Employing these techniques provides a unique opportunity for wide automation and much faster acquisition of data for large spatial extents (satellite, aerial data) (Potter et al. 1993, Huete et al. 2002). Remote sensing techniques have already been used 
in projects aiming at estimation and verification of niches suitable for different ant species (ScotT et al. 2005, Roura-Pascual et al. 2006). Research in this field was conducted on data from aerial or satellite level. This kind of data have limited spatial resolution and, moreover, spectral resolution/number of spectral channels is limited. Limited spatial resolution reduces the range of detection for small patches of specific conditions, but is useful for large extent analyses, in which more rough estimates and general statistics are sufficient and the exact location of land patches is not necessarily important. Importantly, approach presented in this study was much more micro-scale oriented, as single nests and their surroundings were taken into account. Performing this kind of study was possible thanks to modern technology of micro-aerial techniques developed for Remotely Piloted Aerial Systems (RPAS) with miniaturized devices (SAlami et al. 2014, Rey-Carames et al. 2015). Input data resolution of square centimeters delivers higher variance of data, more noise and requires greater amount of work on homogenisation of data sets, but allows much more detailed analysis in diverse ecosystems (in terms of different plant communities and different amount of nutrients/sun/ water).

Depending on spectral range and number of channels in detectors used, it is possible to employ different spectral indices. For purpose of this research, range between 400-1000 nm was considered, which is the range of operation for most popular and lowcost silicon-based sensors. Amongst the most popular indices there is the Normalized Difference Vegetation Index (NDVI). It is a two channel-based index which has been in use since the beginning of multi-spectral remote sensing research. Thanks to simplicity of NDVI, it was used in several analyses of landscapes with ant populations (SCOTT et al. 2005, Plowes et al. 2007, Narenda \& Ramachandra 2008). Another index used in the research is the Modified Chlorophyll Absorption Ratio (MCARI2) with modifications proposed in 2004 by Haboudane (HABOUDANE et al. 2004). This triple wavelength index was proposed to improve correlation between spectral vegetation indices and measurements of Leaf Area Index (LAI), which describes canopies by verifying area of leaves per square unit of ground surface. Research was conducted in Wigry National Park, where LAI is determined in a standard set of measures for integrated environment monitoring (Kostrzewski et al. 2006). As it was mentioned, MCARI2 is more strongly correlated with LAI than NDVI. Therefore, if MCARI2 turns out to be better correlated with environmental features (in our case: ant-related quantities) than NDVI, we will provide theoretical foundation for approximating ant-related quantities basing on LAI, which is determined during standard environmental monitoring. In our research NDVI and MCARI2 were tested for correlation with variables describing ant populations to determine if there are any significant differences between these indices justifying the use of one over the other.

\section{MATERIALS AND METHODS}

Field studies were performed during August 15-29, 2017 in Wigry National Park. Location of measurement plots in the Park was marked on Figure 1. Forty square fields measuring 10 meters by 10 meters were circumscribed: 20 in mixed coniferous forest (phytosociological association Serratulo-Pinetum) and 20 in deciduous forest (phytosociological association Tilio-Carpinetum). Within each field, four square areas measuring 1 meter by 1 meter were marked and investigated for ant nests and foragers (foraging ant workers) of all ant species. Each $10 \mathrm{~m} \times 10 \mathrm{~m}$ field was surrounded by a larger $100 \mathrm{~m} \times 100 \mathrm{~m}$ field, so that the smaller field was situated exactly in the middle of the larger field. The larger field was examined for Formica group ant nests. Ant species were identified. The coordinates of ant collection spots and nest location were determined with the use of GPS.

Remote sensing data was acquired by means of a group of instruments mounted on a medium size RPAS (take-off mass up to $5 \mathrm{~kg}$ ). Hexacopter Versa $\mathrm{X} 6$ drone, produced by Versadrones, was used. It had a total mass of payload around $1.5 \mathrm{~kg}$. Control of drone flight was performed with manual controller for take-off and landing. Flight over measurement point was programmed with autopilot. Flight data including locations, altitude and attitude were registered by 3DR Pixhawk autopilot.

Measurement payload consisted of two Ocean Optics STS micro-spectrometers, one for visible light in range of 355-824 $\mathrm{nm}$ and second for near infrared in range of 633-1123 nm. Spectral resolution of registered data was $3 \mathrm{~nm}$ (digital step $0.47 \mathrm{~nm}$ ). Field of view of spectrometers was $30^{\circ}$. Data from spectrometers were registered on a micro-computer.

Images in visible spectra were taken in intervalometer mode (2s) by GoPro Hero Black $3+$ camera with $4000 \times 3000$ pixels images and $149.2^{\circ}$ field of view. Images from this camera were used for verification of measurement patches scanned by spectrometers and as input corrections of spectra measurements.

For verification purpose Rikola hyperspectral imager (MAKELAINEN et al. 2013) was used in initial flight to calculate spatial distribution of measured vegetation indices in the closest surrounding of measurement point.

Before flight, white target spectrometers were set up with appropriate integration time and dark current. Data were acquired during hovering of RPAS over measurement point, stabilized with GPS. Above each point RPAS spent at least 60 seconds, which allowed for registration of 300-2000 single spectra. 


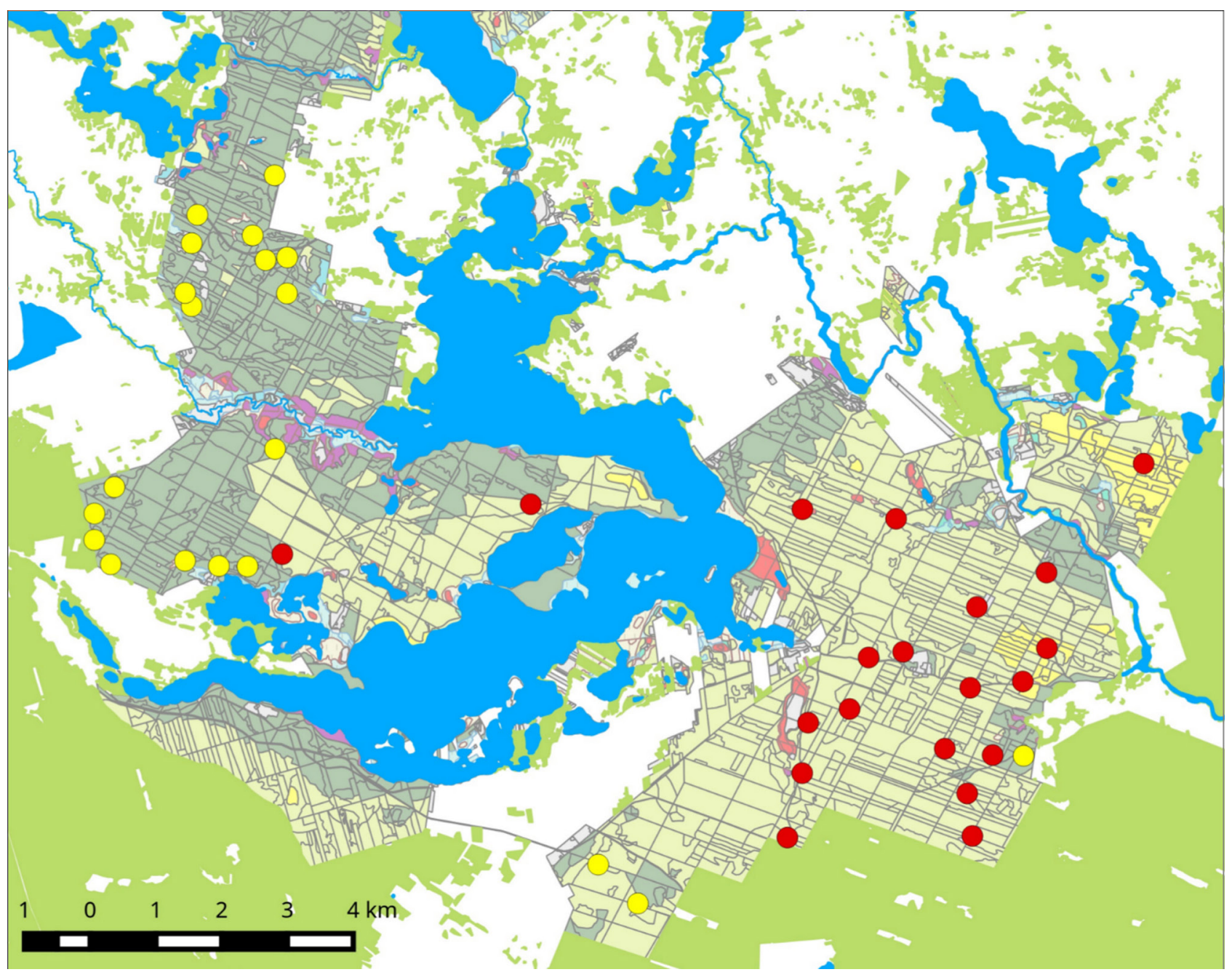

Fig. 1. Location of measurement plots in Wigry National Park. Red circles - mixed coniferous forest (Serratulo-Pinetum), yellow circles - deciduous forest (Tilio-Carpinetum). Map north-oriented

Flight altitude was programmed in such a way, that acquired data contained information from a circular footprint of 30 meters diameter. At the same time, digital camera registered images, which were later used to retrieve canopy model through surface from

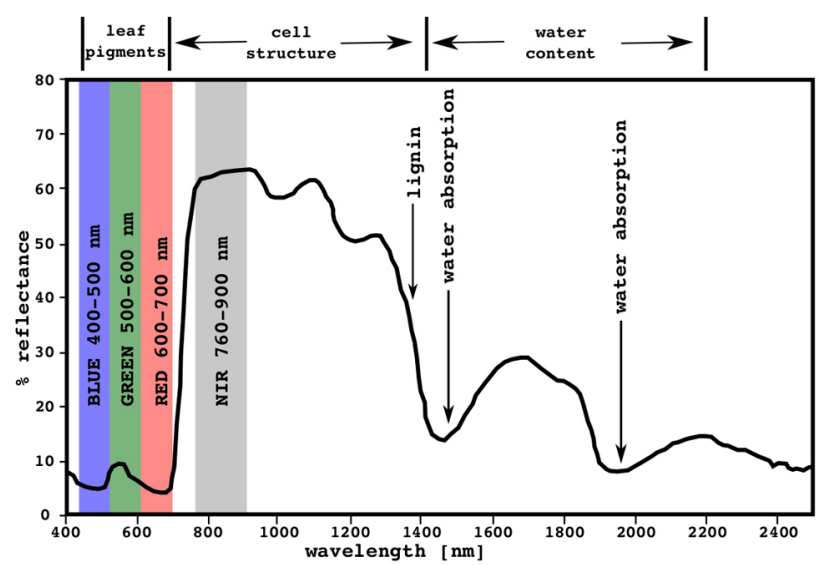

Fig. 2. Reflectance of a model leaf in 400-2450 nm wavelength range with marked spectrum regions for vegetation index analysis (BLUE, GREEN, RED, NIR) motion algorithms. Shape of canopy together with ground data from spectroradiometers were used to apply correction to spectra measured by micro-spectrometers. Atmospheric and geometry correction was performed in lidRadtran radiative transfer library with Mystic 3D solver (MAYER \& KYLLING 2005).

Vegetation indices are proposed based on changes in reflectance of leaf in different spectral regions, which reflect changes in different parameters of leaf (Fig. 2). Between 400-700 nm of visible light spectrum, plant vegetation pigments play crucial role, with especially high absorption of chlorophyll at 465 and $665 \mathrm{~nm}$ (Porra et al. 1989).

In very close near infrared $(700-760 \mathrm{~nm})$, which is already invisible for human eye, a large increase in reflectance of plants is noticeable, which can be explained by the physical structure of leaves, i.e. differences in arrangement of cells (SRIDHAR et al. 2007, Liu et al. 2014). This spectral region is called "the red edge". Difference between reflectance in near infrared (NIR) and the red part of visible spectrum (RED) is the principle of NDVI (Eq. 1). Degradation of chlorophyll causes a decrease in absorption in the 
red range and, as a result, a decrease in NDVI values. Based on changes of NDVI, it is possible to estimate the general vegetation state related with pigments in leaves. Higher values of NDVI are characteristic for vegetation in better condition.

$$
N D V I=\frac{R_{800}-R_{670}}{R_{800}+R_{670}}
$$

MCARI2 was introduced to minimize the influence of chlorophyll content variation and to increase resistance against atmosphere and soil related uncertainties in order to highlight the effects of cells structure and LAI (HABOUDANE et al. 2004). In comparison with NDVI, in MCARI2 there are three wavelengths in total (Eq. 2). Reflectance at $550 \mathrm{~nm}$ was introduced to the formula in order to improve the quantification of changes related with chlorophyll content and to give them appropriate weight. Higher MCARI2 values mean better condition of vegetation.

$$
\text { MCARI2 }=\frac{1.5\left[2.5\left(R_{800}-R_{670}\right)-1.3\left(R_{800}-R_{550}\right)\right]}{\sqrt{\left(2 R_{800}+1\right)^{2}-\left(6 R_{800}+5 \sqrt{R_{670}}\right)-0.5}}
$$

The results were statistically analysed with $U$ Mann-Whitney's test and Spearman's rank correlation coefficient in IBM SPSS Statistics 23 software package.

\section{RESULTS}

\section{DECIDUOUS SITES (TILIO-CARPINETUM)}

In deciduous sites, there were statistically significant correlations between the number or nests from the Formica rufa group and both vegetation indices: NDVI $(\rho=.598 ; p=.007)$, and MCARI2 ( $\rho=.533$; $p=.019)$. The bigger the number of nests was, the higher the vegetation indices were. The size of all correlations was large. Furthermore, $U$ Mann-Whitney's tests proved that in the areas where at least one Formica group nest was present, the vegetation indices were higher than in areas without any Formica group nest (accordingly: NDVI: $Z=-2,57 ; p=$ .010 ; MCARI2: $Z=2,34 ; p=.025)$. This implies that the sole presence of $F$. rufa group ants was connected with higher vegetation indices.

Moreover, there was a large statistically significant correlation between the number of Formica polyctena and $F$. rufa foragers and the value of NDVI ( $\rho=$ $.533 ; p=.019)$. The bigger the number of foraging ants was, the higher the values of the index. At the same time, the correlation between the number of $F$. polyctena and F. rufa foragers with MCARI2 value was moderately strong and not statistically significant.

As for other ant species recorded in the field, the only statistical tendency was the correlation between
MCARI2 value and the number of Lasius platythorax nests $(\rho=.442 ; p=.058)$. This correlation was positive but only moderately big. The correlation between the number of L. platythorax nests and the NDVI was not statistically significant. Moreover, there were no statistically significant or nearly statistically significant correlations between vegetation indices and the number of nests of Myrmica ruginodis, Myrmica rubra nor the overall number of non-Formica nests nor the number of foragers in the examined area.

\section{CONIFEROUS SITES (SERRATULO-PINETUM)}

In coniferous sites, there was a strong, statistically significant correlation between the number of $F$. rufa group nests and the MCARI2 value $(\rho=.637 ; p=$ .019). The correlation was positive, meaning that the bigger the number of nests was, the higher the MCARI2 value was. Strong, nearly statistically significant correlations regarded the number of $F$. rufa group nests and the NDVI $(\rho=.516 ; p=.071)$. Furthermore, $U$ Mann-Whitney's tests proved that in the areas where at least one Formica group nest was present, the MCARI2 $(Z=2,32 ; p=.021)$ and NDVI $(Z=-1,70 ; p=.090)$ vegetation indices were higher than in areas without any Formica group nest.

Table 1. Correlation between vegetation indices and the number of ant nests in the research area in coniferous places

\begin{tabular}{lcrc}
\hline & & NDVI & MCARI2 \\
\hline Myrmica ruginodis & $\rho$ & -.675 & -.628 \\
Myrmica rubra & $\mathrm{p}$ & .011 & .022 \\
& $\rho$ & -.019 & .070 \\
Lasius platythorax & $\mathrm{p}$ & .951 & .821 \\
\multirow{2}{*}{ Total number of ant nests } & $\rho$ & -.513 & -.513 \\
& $\mathrm{p}$ & .073 & .073 \\
& $\rho$ & -.676 & -.696 \\
& $\mathrm{p}$ & .011 & .008 \\
\hline
\end{tabular}

There were statistically significant large correlations between the values of both vegetation indices and the number of $M$. ruginodis nests and the overall number of non-Formica nests (Table 1). The correlations were negative, meaning that the higher the number of nests was, the lower the values of indices were. Moreover, there were nearly statistically significant correlations between values of both vegetation indices and the number of L. platythorax nests. Similarly, the correlations were negative and large. There were no other statistically significant correlations.

\section{DISCUSSION}

The relation between ant communities and vegetation indices is indirect. That was expected due to indirect influence of environmental factors on indices alone. 
The general conclusion for deciduous forest states that indices are positively correlated with ant-related quantities (number of nests, number of foragers). NDVI and MCARI show the same tendency, suggesting that both indices perform comparably in these conditions. It should be noted that the positive correlation between indices and ant-related quantities concerns almost exclusively Formica ants. As for the other ants, only the number of $L$. platythorax nests was linked to MCARI2 values. Other ant-related variables concerning Lasius sp. or Myrmica sp. did not correlate with NDVI or MCARI2 indices. The link between high values of Formica ant-related quantities and high values of indices (i.e. better state of vegetation) could be explained by the fact that Formica ants penetrate the environment much more intensively than Lasius or Myrmica ants. Moreover, Vele \& Modlinger (2016) proved that $F$. polyctena ants do not focus solely on food of certain size or quality. Therefore, in a resource-rich environment, such as deciduous forest, Formica ants can benefit from abundant and diverse food base to a much larger extent than Lasius or Myrmica ants, which have specific food preferences. At the same time, high availability of diverse food sources in deciduous forest alleviates aggressive interspecies interactions (DE BRUYN \& MABELIS 1972). Therefore species like L. platythorax and Formica sp. could coexist. This explains the positive correlation between the number of $L$. platythorax nests and vegetation indices.

Coniferous forest is not as resource-rich in diverse food sources as deciduous forest and observed correlations differ in some aspects. In coniferous forest number of Formica group nests was positively correlated with MCARI2 index. NDVI showed the same direction of correlation, however, results were only nearly significant. Correlation between presence and number of Formica group nests and vegetation indices in both types of forests is consistent with the positive influence of Formica ants on the "sanitary state" of tree stands. On the other hand, correlation of both indices with the number of $M$. ruginodis and L. platythorax ant nests and overall number of non-Formica ant nests in coniferous forest demonstrates negative values. This result suggests that areas of weaker vegetation were preferred by mentioned non-Formica species of ants, rather than that Myrmica or Lasius ants can deteriorate the condition of tree stands. However, ants are known to feed on sugar-rich honeydew, produced by destructive insect pests, such as aphids (ADDicotT 1978). Some ant species form symbiotic interactions with aphids and tend them (Novgorodova 2005). Nevertheless, these interactions concern not only Myrmica or Lasius ants, but also Formica ants, whose presence can even lead to an elevation in the number of aphids (SKINNER \& WHITTAKER 1981). Therefore, weaker vegetation indices in places where Myrmica or Lasius ants are present can not be explained by higher number of plant-damaging aphids.
More likely, in coniferous forest, which is generally poor in resources, the antagonistic interactions between Formica ants and Myrmica and Lasius ants are more intense. De Bruyn (1977) pointed at fierce interspecific competition between $F$. polyctena and $M$. ruginodis. Supposedly the weaker species (Myrmica and Lasius) are present in those areas, where the Formica pressure is lower - i.e. areas of weaker vegetation. This is consistent with MABELIS works (1983). At the same time, small number of Formica ants and lack of their "sanitary function" in those areas may contribute to maintenance of low vegetation indices. However, due to different methodology used in examination of Formica and non-Formica ants, is difficult to determine the direct link between presence and number of workers of Formica ants and Myrmica and Lasius ants.

In coniferous forest number of Formica group nests was positively correlated with MCARI2 index. NDVI showed the same direction of correlation, but results were only nearly significant. This was the only test where MCARI2 provided better results in term of significance than NDVI. Despite quite similar range of LAI (AsNeR et al. 2013) and chlorophyll content (Eitel et al., 2011) in both types of forest, in case of coniferous forest the measured values of indices were significantly lower. Combined influence of leaf shape, wax layer thickness and thickness of cuticle account for weaker reflectance and darker color of needles in comparison with broadleaves. Supposedly, NDVI is more dependent on these features of leaves. As it can be seen, in coniferous forest MCARI2 could reveal changes which are below the detection level of NDVI. These results should be further investigated during continuation of research.

In the presented data differences between MCARI2 and NDVI are occasional, which suggests that there is no need to use the more complex index (MCARI2) in order to differentiate niches in the area of research. At the same time, our results do not provide evidence of direct influence of LAI on quantities related to ants communities, which comes out from lack of significantly higher correlations of ant-related quantities with MCARI2 (index designed to better correlate with LAI) than with NDVI. It means that, at the moment, measurements of LAI made during environmental monitoring in the park cannot be easily used for ant related research. Comparison of vegetation indices for reasoning related with ants was not widely tested by researchers, but presented results show, that use of NDVI in majority of studies is fully justified and sufficient.

\section{CONCLUSIONS}

Presented results suggest that vegetation indices could be used for initial preselection of places preferred by ants from Formica group. In both types of 
forests, higher values of indices were correlated with greater occurrence of these species. On the other hand, presence of Myrmica and Lasius ants was either negatively correlated or not correlated with vegetation indices, depending on the type of forest. In future research it would be crucial to determine whether these tendencies result from interspecific interactions or rather direct relations with the environment. In order to elucidate these matters it would be necessary to change the methodology applied to all ant species.

There are no strong differences in correlations of NDVI and MCARI2 with ant-related parameters. Taking this into account, we conclude that NDVI is sufficient for such studies. Using MCARI2 involves higher costs, requires bigger amounts of data and there are no easily accessible processing solutions for MCARI2. Choosing NDVI has several advantages, as it enables using NDVI dedicated cameras, which nowadays have reasonable prices and deliver ready to use NDVI spatial distribution pictures, where necessary processing is performed internally.

\section{ACKNOWLEDGEMENTS}

The study was financially supported by Fundusz Leśny, under the agreement between Państwowe Gospodarstwo Leśne Lasy Państwowe and Wigry National Park (EZ.0290.1.39.2017) - "Myrmekofauna zbiorowisk leśnych Wigierskiego Parku Narodowego i dynamika jej zmian na tle zdrowotności drzewostanów, badanej przy użyciu zdjęć spektralnych".

\section{REFERENCES}

Addicott J.F. (1978): Competition for mutualists: aphids and ants. Canadian Journal of Zoology 56(10): 2093-2096.

Adlung K.G. (1966): A critical evaluation of the European research on use of red wood ants (Formica rufa group) for the protection of forests against harmful insects. Zeitschrift für Angewandte Entomologie 57: 167-189.

AsNer G.P. (1998): Biophysical and biochemical sources of variability in canopy reflectance. Remote Sensing of Environment 64(3): 234-253.

AsNer G.P., SCURLOCK J.M.O., Hicke J.A. (2003): Global synthesis of leaf area index observations: implications for ecological and remote sensing studies. Global Ecology and Biogeography 12(3): 191-205.

DE BRuYN G.J. (1977): Food Territories in Formica Polyctena Forest. Netherlands Journal of Zoology 28(1): 55-61.

De Bruyn G.J., Mabelis A.A. (1972): Predation and aggression as possible regulatory mechanisms in Formica. Ekologia Polska 20: 93-101.

Czechowski W., Radchenko A., Czechowska W., VepsäLÄINEN K. (2012): The ants of Poland with reference to the myrmecofauna of Europe. Natura optima dux Foundation, Warszawa.

Eitel J.U.H., Vierling L.A., Long D.S., Litvak M., EITEL K.C.B. (2011): Simple assessment of needleleaf and broadleaf chlorophyll content using a flatbed color scanner. Canadian Journal of Forest Research-Revue Canadienne De Recherche Forestiere 41(7): 1445-1451.

Farji-Brener A.G., Werenkraut V. (2017): The effects of ant nests on soil fertility and plant performance: a meta-analysis. Journal of Animal Ecology $86(4)$ : 866-877.

Frouz J., JiLKovÁ V. (2008): The effect of ants on soil properties and processes (Hymenoptera: Formicidae). Myrmecological News 11(11): 191-199.

Gamon J.A., Field C.B., Goulden M.L., Griffin K.L., Hartley A.E., Joel G., Valentini R. (1995): Relationships between NDVI, canopy structure, and photosynthesis in 3 Californian vegetation types. Ecological Applications 5(1): 28-41.

Haboudane D., Miller J.R., Pattey E., Zarco-Tejada P.J., StRAchan I.B. (2004): Hyperspectral vegetation indices and novel algorithms for predicting green LAI of crop canopies: Modeling and validation in the context of precision agriculture. Remote Sensing of Environment 90(3): 337-352.

HÖLLDOBLER B., Wilson E.O. (2009): The superorganism. W.W. Norton, New York.

Huete A., Didan K., Miura T., Rodriguez E.P., Gao X., FERREIRA L.G. (2002): Overview of the radiometric and biophysical performance of the MODIS vegetation indices. Remote Sensing of Environment, 83(1-2): 195-213.

Kostrzewski A., Kruszyk R., Kolander R. (2006): Integrated monitoring of environment. The principles of organization, the measuring system, the selected test methods. http://zmsp.gios.gov. pl/?page_id=69 (access: 27.09.2018).

Liu L.Y., HuANG W.J., Pu R.L., Wang J.H. (2014): Detection of internal leaf structure deterioration using a new spectral ratio index in the near-infrared shoulder region. Journal of Integrative Agriculture 13(4): 760-769.

Mabelis A.A. (1983): Interference between wood ants and other ant species (Hymenoptera, Formicidae). Netherlands Journal of Zoology 34(1): $1-20$.

Makelainen A., SaAri H., Hippi I., Sarkeala, J., SoukKAMAKI J. (2013): 2D hyperspectral frame imager camera data in photogrammetric mosaicking. Uav-G2013: 263-267.

Mayer B., Kylling A. (2005): Technical note: The libRadtran software package for radiative transfer calculations - description and examples of use. Atmospheric Chemistry and Physics 5: 1855-1877.

Novgorodova T.A. (2005): Ant-aphid interactions in multispecies ant communities: Some ecological 
and ethological aspects. European Journal of Entomology 102(3): 495.

OhASHi M., Kilpeläinen J., Finér L., Risch A.C., Domisch T., Neuvonen S., Niemelä P. (2007): The effect of red wood ant (Formica rufa group) mounds on root biomass, density, and nutrient concentrations in boreal managed forests. Journal of Forest Research 12(2): 113-119.

Porra R.J., Thompson W.A., Kriedemann P.E. (1989): Determination of accurate extinction coefficients and simultaneous-equations for assaying chlorophyll-a and chlorophyll-b extracted with 4 different solvents - verification of the concentration of chlorophyll standards by atomic-absorption spectroscopy. Biochimica et Biophysica Acta 975(3): 384-394. doi:10.1016/s0005-2728(89)80347-0.

Potter C.S., Randerson J.T., Field C.B., Matson P.A., Vitousek P.M., Mooney H.A., Klooster S.A. (1993): Terrestrial ecosystem production - a process model-based on global satellite and surface data. Global Biogeochemical Cycles 7(4): 811841.

Prentice I.C., Cramer W., Harrison S.P., Leemans R., Monserud R.A., Solomon A.M. (1992): A global biome model based on plant physiology and dominance, soil properties and climate. Journal of Biogeography, 19(2): 117-134.
Rey-Carames C., Diago M.P., Martin M.P., Lobo A., TARDAGUila J. (2015): Using RPAS Multi-Spectral Imagery to Characterise Vigour, Leaf Development, Yield Components and Berry Composition Variability within a Vineyard. Remote Sensing 7(11): 14458-14481.

Salami E., Barrado C., Pastor E. (2014): UAV Flight experiments applied to the remote sensing of vegetated areas. Remote Sensing 6(11): 1105111081.

SkinNer G.J., Whittaker J.B. (1981): An experimental investigation of inter-relationships between the wood-ant (Formica rufa) and some tree-canopy herbivores. The Journal of Animal Ecology 50: 313-326.

Sridhar B.B.M., Han F.X., Diehl S.V., Monts D.L., Su Y. (2007): Spectral reflectance and leaf internal structure changes of barley plants due to phytoextraction of zinc and cadmium. International Journal of Remote Sensing 28(5): 1041-1054.

VéLe A., Modlinger R. (2016): Foraging strategy and food preference of Formica polyctena ants in different habitats and possibilities for their use in forest protection. Forestry Journal 62 (4): 223-228.

Zhang X.Y., Friedl M.A., SchaAf C.B., Strahler A.H., Hodges J.C.F., Gao F., Reed B.C., Huete A. (2003): Monitoring vegetation phenology using MODIS. Remote Sensing of Environment 84(3): 471-475. 